\title{
Underpinning the entrepreneurship educator's toolkit: conceptualising the influence of educational philosophies and theory
}

\section{Robin Bell ${ }^{1}[$}

Received: 13 October 2020 / Revised: 30 November 2020 / Accepted: 7 December 2020 /

Published online: 7 January 2021

(c) The Author(s) 2021

\begin{abstract}
Entrepreneurship educators can maximise the effectiveness of their delivery by having a firm grasp of the different educational philosophies and theories that underpin entrepreneurship education pedagogy and practice. A particular educational philosophical orientation underlies, directs, and drives educator practices and should align with what the teaching seeks to impart and achieve, and the roles the learners and educator play in the learning process. Whilst educators might not always be explicitly aware of their philosophical orientation, it will direct and drive their pedagogic practice and have implications for what they deliver, and how they deliver it. The benefits of bringing together different learning theories, philosophies, and approaches for entrepreneurship education has previously been posited in the literature. However, it has been highlighted that connections between educational theory and practice are limited, and that the field of entrepreneurship education could be advanced through providing links between education literature, theory, and learning. This paper advances the literature by linking educational philosophy and theory to entrepreneurship education and pedagogy in higher education. It discusses and highlights how behaviourism, cognitivism, constructivism, and humanism can be used to underpin and support learning in entrepreneurship education. This meets calls for the conceptualisation of how educational philosophies and theories can be integrated into entrepreneurship education to support learners.
\end{abstract}

Keywords Philosophy of education - Entrepreneurship pedagogy $\cdot$ Educational theory $\cdot$ Cognitivism $\cdot$ Constructivism $\cdot$ Humanism

Robin Bell

r.bell@worc.ac.uk

1 Worcester Business School, University of Worcester, Worcester, UK 


\section{Introduction}

Whilst a rapid increase has taken place globally in the access and availability of entrepreneurship education over the last twenty years (Fayolle 2013; Neck and Greene 2011), there remains the need for intellectually robust entrepreneurship education foundations. Such foundations should be robust at both a theoretical and methodological level (Pittaway and Cope 2007). However, it has been highlighted that limited literature exists linking educational theory and philosophy to entrepreneurship education; separation between educational literature and concepts of entrepreneurship education remains (Fayolle 2013). Whilst entrepreneurship education is a fast-developing field with room to grow, educational science has a long and distinct history that entrepreneurship education can leverage to develop and underpin its pedagogy.

Entrepreneurship educators have often had to find their own way in their pedagogic practice (Lackéus et al. 2016; Neck and Corbett 2018) and have had a limited understanding of the key educational theories and philosophies underpinning their practice. Hannon (2006) highlighted the importance of educators understanding how educational philosophies and theories inform the different pedagogies to achieve different educational objectives. This becomes challenging in entrepreneurship education, given the extensive and diverse objectives and pedagogical approaches from different learning activities (Ramsgaard 2018). Robinson et al. (2016) highlighted the benefits of bringing together different learning theories, philosophies, and approaches in entrepreneurship education to support learner-centred approaches, which they argue, could encourage and develop entrepreneurial awareness. Indeed, Brieger et al. (2020) highlight that there is no such thing as adult learning theory, but rather there are many philosophies and theories. Therefore, there is a need to carefully apply educational philosophies and learning theories to support learning goals and meet the needs of the learner.

Even though entrepreneurship education is inextricably related to education and education principles, philosophy and theory, only limited connections between education scholarship and entrepreneurship education practice and learning have been developed (Fayolle et al. 2016). Indeed, whilst entrepreneurship education scholarship and research is developing, there remain areas that need to be addressed, including developing the linkages between education literature, theory and learning (Neergaard et al. 2020). Bell and Bell (2020) have called for future work to investigate and conceptualise how a range of educational philosophies and theories can be integrated into entrepreneurship education to support learners. This paper meets these calls and contributes to the literature by linking educational philosophy and theory to entrepreneurship education and by exploring and conceptualising how the educational approaches of behaviourism, cognitivism, constructivism and humanism can be applied to support learning in entrepreneurship education. Although this paper considers these approaches within the context of higher education, the approaches and the reasoning behind their application could have transferability to educators at different levels and in different settings. 


\section{Theoretical underpinning of entrepreneurship education}

\section{The role of educational philosophy and theory in entrepreneurship education}

Understanding underpinning educational philosophical frameworks helps educators better grasp why and how they teach (Hannon 2006). Educational philosophies and theories are interlinked and inform pedagogic practice and the learning process of students and therefore it is important for educators to understand these to maximise the effectiveness of their teaching (Bell and Bell 2020). However, educator narratives often highlight a limited depth of knowledge and understanding of the underpinning educational philosophies and theories (Fayolle et al. 2016). Jones (2019) has highlighted that a concise philosophy of entrepreneurship education does not exist and Ramsgaard (2018) suggests that no single philosophy or learning theory can be effective in underpinning the diverse pedagogical approaches involved in entrepreneurship education (Ramsgaard 2018). Educational philosophies and theories inform the learning process and can guide educators through the contrasting landscapes of educational approaches (Ramsgaard 2018). The educational philosophy chosen informs and guides teaching practice and contributes to professionalism, as having a philosophic orientation differentiates those educators who are aware of what they are doing and why they are doing it (Merriam 1982). The underlying philosophy and theory of learning adopted by educators drives their thinking, behaviour, and action, as educators make decisions and act in ways that presuppose certain values and beliefs. Whether or not it is articulated, a philosophical orientation underlies, directs, and drives educator practices (Darkenwald and Merriam 1982). Whilst, educators might not explicitly choose a philosophy or theory of learning to underpin their teaching but rather follow a path of least resistance, or subconsciously adopt one, it will still have implications on what they deliver, how they deliver it and how they assess learners.

Within higher education, entrepreneurship education is increasingly being viewed as important for all learners, regardless of learner discipline or future career goals (Bell and Bell 2016; O’Brien et al. 2019). Even if learners are not planning on starting a business in the near future, the literature has highlighted that entrepreneurialism and entrepreneurial behaviour can support the learner's employability (Bell 2016), which is high on many educational institutions' agendas (Sewell and Dacre Pool 2010). Entrepreneurship education can take many forms and can have a range of educational objectives. Zhang (2020) highlighted that entrepreneurship education should be viewed as broader than only venture creation and Nabi and Holden (2008) opined that it might be useful to consider enterprise/entrepreneurship as a spectrum ranging from broad and generic skills relevant to most students, to more specific and specialised skills for entrepreneurs, who may be more interested in starting a business. Different entrepreneurship education approaches have been identified as being able to teach the 'about' entrepreneurship which teaches the theory behind entrepreneurship; 'for' entrepreneurship which develops learners entrepreneurial skills and competences so 
that they are ready for potential entrepreneurial endeavours; and 'through' entrepreneurship which supports learning by the practicing of entrepreneurship (Hannon 2005). Each of the three types of entrepreneurship education achieves different types of learning and provides different benefits to the learner. A grounding in the theory underpinning entrepreneurship and the 'why' and 'how' to be entrepreneurial can be delivered by an 'about entrepreneurship approach'. Learners can develop general entrepreneurial skills and competences which can support employability (Bell 2016) and enable entrepreneurial behaviours in the future using a 'for' entrepreneurship approach; and learning by practice can enable learners to practice entrepreneurial activity using a 'through' entrepreneurship approach (Bozward and Rogers-Draycott 2020).

The value and purpose of entrepreneurship education is driven by contrasting and often conflicting beliefs, which emanate from deeply rooted philosophical underpinnings (Hannon 2006). As entrepreneurship education encompasses a wide range of potential educational goals and objectives, a range of different educational philosophies and theories can be adopted to underpin the approach and pedagogy undertaken. Hannon (2006) highlighted that to develop and support successful entrepreneurship education a more sophisticated approach which acknowledges the wide educational philosophical and conceptual base is required. It is essential for educators to understand the different educational philosophies and theories that can be used to underpin and ground entrepreneurship education pedagogy and practice, as these inform and provide a deeper understanding of the way to deliver entrepreneurship education and the justification and reasoning behind it (Hannon 2006). It is commonly understood that it is important to ensure alignment between the learning objectives of the course, the pedagogy and the assessment (Biggs 2012), and by aligning philosophy with learner expectations, requirements, and intended outcomes, it is more likely to lead to an improved learner experience (Hannon 2006). The underpinning educational philosophy and theory of learning should be in alignment with what the teaching seeks to impart and achieve, and the roles of the learners and educator in the learning process (Bell and Bell 2020). In light of this, it has been highlighted that education scholars have great potential to contribute to the breadth of teaching practices that can be incorporated into contemporary knowledge and literature on entrepreneurship education (Neergaard et al. 2020). The following sections of this paper will review and discuss how and why the educational philosophies and learning theories of behaviourism, cognitivism, constructivism, and humanism can used to underpin entrepreneurship education. Importantly, the underpinning educational philosophy and theory of learning should align with the educator's objectives and the roles of the educator and learners within the learning process.

\section{Behaviourism}

The epistemological base of traditional didactic teaching is the view that knowledge is an objective phenomenon, and that reality exists independently of the observer and can be discovered to achieve verifiable facts about the external or 
real world. In the behaviourist approach, learning is equated with either the form or frequency of observable performance (Ertmer and Newby 2013). Educators thus take a behavioural approach that involves efficient and functional mechanical processes (Löbler 2006). A behaviourist teaching approach seeks to shape the learner's growth and development in a particular direction (Bruner 1966) and thus does not seek to encourage criticality or judgement (Dewey 2013). Repetition, reinforcement, and testing are important teaching elements in this approach. However, a system in which the educator solely provides knowledge for the learner to 'bank' can stifle the learner's creativity (Freire 2006). It has also been suggested that the transfer of passive knowledge can lead to learners disengaging or becoming 'surface learners' who are only required and able to repeat the information back (Bennett 2006; Trigwell et al. 1999). Although commonplace in entrepreneurship education, it is increasingly considered limited in its usefulness, specifically for providing theoretical entrepreneurship knowledge and instruction (Gedeon 2014). Despite this, education may be delivered passively through expediency and thus is not philosophically or pedagogically informed.

Traditionally, management and business studies were impacted by the pedagogy of economics, which in turn was derived from the teaching practices within natural sciences (Mirowski 1989). Pedagogy within such fields were delivered in a mechanistic approach, where the learner would act as an outside observer and would capture abstract theories and models delivered by the educator (Dierksmeier 2011). What matters in such an approach is the quantity and quality of the material and knowledge delivered, rather than the quality of the personal experience of the learner (Dierksmeier 2020). Knowledge delivered via such an approach can be devoid of context and not related to the previous experiences of the learner. Such behaviourist approaches to entrepreneurship education suggest that entrepreneurs need objectivist knowledge to get their jobs done effectively and efficiently, and that 'knowing that' is more important than the 'know how'.

Behaviourism has been identified as a suitable approach to support the didactic delivery of objectivist knowledge. The role of the educator is to manage, predict and direct the learning outcomes and in so doing, meets the needs of society and industry through compliance with identified standards of skills and behaviour (Hannon 2006). It is thus an efficient way of teaching 'about' entrepreneurship but is increasingly considered to be more suitable for the teaching of theoretical education and the delivery of instructional information. It can, however, provide the underlying frameworks against which learners can analyse and understand their own experiences in the real world (Jack and Anderson 1999; Peltier and Scovotti 2010). Similarly, learners undertaking constructivist exercises will need both instructional information and a solid grounding in the topic area that forms the basis of the constructivist learning. Objectivist approaches are needed to provide this background (Bell and Bell 2020); and Béchard and Toulouse (1998) highlighted the need for entrepreneurship educators to use a didactic approach to ensure learners can define and understand the course's objectives. Behaviourism, however, has limitations in supporting the application of learnt knowledge; cognitivism builds on behaviourism by supporting the processing and application of objectivist knowledge. 


\section{Cognitivism}

Learning theories based on the cognitive sciences became popular in the late 1950's. Cognitivism represented a shift from behaviourism as it considered the psychology behind learning to be a cognitive process, which involves the processing of knowledge, not only the memorisation of it (Brieger et al. 2020). As a result, compared to the behaviourist approach the learner plays a more active role in the learning process. The cognitive paradigm posits that objective knowledge can be developed and is drawn from rationalism, and postulates that knowledge can be reached through reasoning or intellectual intuition (Kyrö 2015). Cognitivists consider learning to be an internal process that involves the memorisation of information, thinking and reflecting on the information and then abstraction of the information (Ally 2004). The cognitive approach equates learning with changes between states of knowledge, and knowledge is considered in terms of internal coding and structuring by the learner through the learning process (Ertmer and Newby 2013). Cognitivism is thus focused on individual cognitive processes and the level of cognitive development of the individual being taught (Bandura 1977), and learning is the result of learners' thinking critically in order to process information to create new knowledge. It has an objectivist view that once the knowledge is taught and understood, the knowledge can then be used and transferred into other situations. However, as cognitivist educational theory encourages critical thinking and appraisal of knowledge, it appreciates that no knowledge is truly secure and incontestable over time or in different contexts, and this can motivate learners to continue to learn and challenge existing concepts (Morris 2019a). Such learning can be suitable for situations where uncertainty and ambiguity exist (Bruner 1966), such as within entrepreneurship.

Cognitivist approaches are often adopted to support the development and nurturing of reasoning and critical thinking skills, which can be defined as "thinking that is purposeful, reasoned and goal directed - the kind of thinking that is involved in solving problems, formulating inferences, calculating likelihood, and in making decisions" (Halpern 1996, p. 5).

Despite the fact that critical thinking has been identified as an essential tool of enquiry (Facione 1990), it has been suggested that there is a current lack of emphasis on developing learners' critical thinking in business and management education (Örtenblad et al. 2013). This is despite the fact that Meyers (1986) argued that critical thinking is a vital skill to allow learners to achieve their full potential and that it has been proposed as a valuable and essential attribute for graduates in the twentyfirst century (Huitt 1998). Such critical thinking skills and abilities are important within entrepreneurship where entrepreneurs must process existing knowledge to unique and changing scenarios to inform their business decision making.

The focus of the cognitive process is on changing the learner by encouraging them in using appropriate learning strategies. The role of the educator is to facilitate and promote learning as a partner, but not directing it (Hannon 2006). To support the learner to assimilate and process information and knowledge, the educator should present this in a clear and linear fashion (Merriam et al. 2007).

Cognitivist teaching approaches often include case studies and activities in which critical analysis of the case, or information within the activity, can lead to the 
development of learners' critical thinking skills. Kantar (2013) has highlighted that case-based learning is a popular approach, grounded within a cognitivist approach to teaching, as it allows learners to process and apply their existing knowledge in order to develop critical insights, which promote theoretical understanding. In such learning, a learner's prior knowledge about a subject is critically applied to a teaching activity (Arghode et al. 2018; Chakraborty and Muyia Nafukho 2014). Teaching activities and their complexity should be related to the learner's prior knowledge, to ensure that learners can engage with the teaching activities critically (Brieger et al. 2020). For example, if learners are presented with a case study or activity, they should have the knowledge of the concepts within it to critically appraise it and apply their knowledge in order to provide reasoned arguments and judgements. Teaching should therefore focus on the cognitive processes of structuring, storing, and retrieving knowledge, so that it can be critically related and applied to new concepts and scenarios (Brieger et al. 2020).

However, in terms of entrepreneurial development, cognitivism does not take into consideration the arguably experiential nature of entrepreneurial learning (Rae 2005) that comes as a result of learning from doing and reflecting on the process (Cope 2005; Mezirow 1990). Therefore, in the context of preparing learners for entrepreneurship, cognitivist approaches are limited as they disregard the importance of developing reflexivity and self-awareness (Ferreira 2020). Constructivism has been posited to overcome several of the shortcomings in preparing learners for entrepreneurship, which have been levelled at approaches based on behaviourism and cognitivism.

\section{Constructivism}

The epistemological base of traditional teaching underpinned by behaviourism and cognitivism is that knowledge is an objective phenomenon. This has been increasingly challenged by constructivism and constructivist approaches to learning, that are based on an epistemology of knowledge that is based instead on the subjective understanding of an individual. Constructivism is a theory of knowledge (Gergen 2015) which emphasises the role of the individual in creating their own individual meaning from knowledge in relation to their own context and experience (Mueller and Anderson 2014). In constructivism, knowledge resides in the individual (Lorsbach and Tobin 1992) and learning, and knowledge construction is an active and interpretive process, where meaning-making is dependent on past and present knowledge (Merriam et al. 2007). As a result, this changes the role that the educator plays. This approach has challenged the dominant view of knowledge as being objectivist, and how it should be acquired in entrepreneurship education (Löbler 2006).

Constructivists argue that individuals play an active role in their knowledge construction and that learning is achieved when they try to make sense of new information or input by filtering it against their past experiences and existing knowledge to build a new knowledge framework and understanding (Snowman and Biehler 2006). The new knowledge or skills are internally built on past 
knowledge and experience. Constructivism is thus based on the active participation of the participant which has led to the creation and development of active learning in real life situations, independent thinking, and the framing of selfquestions in the process of discovery (Mathews 2007). Jonassen (1999) argued that the fundamental difference in constructivist learning is that it involves learners solving an issue, question, case, problem, or project which is situated in a real-world context.

It has been suggested that approaches rooted in constructivism are superior for entrepreneurship education (Balan and Metcalfe 2012; Kyrö 2015), as this can most effectively support experiential learning which is particularly efficacious (e.g., Fuchs et al. 2008; Honig 2004). Previous research has suggested that constructivist learning is one of the steppingstones for developing entrepreneurial behaviours (Bell 2020a). As constructivism emphasises the creation of new meaning from new knowledge created through experiences and problem solving, it provides a more effective explanation of how knowledge is created within the fast-moving and dynamic context of entrepreneurship. This means that the learning and meaningmaking process is related to the context where the problem solving occurs, which enables a deeper conceptual understanding and an appreciation that a solution will not work in all situations and contexts (Morris 2020). Such an approach to learning can prepare learners for entrepreneurship where different solutions are required to meet entrepreneurial challenges and problems depending on the situation and context.

Korsgaard and Anderson (2011) have suggested that entrepreneurship is both a social and economic process in which networking and social interaction plays a prominent role and Rae (2005) opined that entrepreneurship and learning are inherently constructivist and social processes. This suggests that a social constructivist approach could effectively underpin entrepreneurship education.

As constructivism emphasises the role of learners in creating their own meaning from knowledge in context (Mueller and Anderson 2014), this lends itself to action-based learning through which learners must construct their own interpretations of their world through interactions with their surroundings (Mathews 2007). This is particularly relevant in higher education where there is an emphasis on individual self-guided learning in which learners are responsible for their own development. In this approach, learners take part in a constructivist-based active experiential learning process to solve problems presented by the educator (Jonassen 1999). Authentic experiences are most effective for learning outcomes and engagement (Macht and Ball 2016). The educator must ensure that the process is constructively aligned (Biggs 2012), and that learners fully understand the process, the objectives and the assessment procedure if being assessed. The educator provides 'scaffolding,' guidance as and when required, to enable learners to undertake the learning process (Hmelo-Silver et al. 2007). The learners then reflect on their learning experience, which can be assessed through learner's reflective logs or accounts. Effective constructivism learning should include reflection to provide meaning to the learner through understanding of the experience (Hägg and Kurczewska 2016), and its link to real-world application. Structured approaches to reflection can enhance reflection, particularly if learners are not used to reflection (Platzer et al. 1997). 
Although these three approaches are utilised most commonly to underpin education (Bélanger 2011) and entrepreneurship education (Bell and Bell 2020), there remain, however, other underrepresented and underutilised educational philosophies that can bring unique and specific benefits to undergraduate entrepreneurship education, including that of humanism.

\section{Humanism}

Whilst there is yet to be consensus as to an all-encompassing definition of humanistic education and what it involves, there is agreement that humanistic learning environments should support and facilitate the development of the whole person, including their intellectual, socioemotional, and physical development (Aloni 2002). The primary concern of humanism is the autonomy and dignity of human beings; it therefore focuses on the learner's personal choice and commitment to support their development (Billings and Halstead 2019). The axiological component of the humanistic philosophy is compassion. This can be manifested in compassion to others, through respectful interpersonal interactions, and more generally to society. This dovetails well with the objectives and behaviours which many higher education institutions seek to distil in their graduating learners.

Humanism promotes the acquisition of value-oriented skills and the development of integrative judgments within learners, whilst de-emphasising the route memorisation of knowledge promoted by behaviourism and analytical specialisation and the focused critical thinking promoted within cognitivism (Freire and Faundez 1989; Eisler et al. 1990; Solberg et al. 1995; Hmelo-Silver 2004; Lester et al. 2005). Learning from a humanist perspective is seen as a personal act to fulfil development through affective and developmental needs, with a view to becoming self-actualised, mature, and autonomous. The educator thus acts to facilitate the wider development of the whole person, in a liberating environment (Merriam et al. 2007).

Within general business education, there has been a humanistic transformation of management pedagogy (Dierksmeier 2016), which has supported calls for developing learners' skills and competencies to help them act in a socially, ecologically, and morally sustainable manner in their future careers (Dierksmeier 2020). Within other educational philosophies, there has been limited attention paid to how the education influences the learners, the corporate environments and the society that they will end up in (Morrell and Learmonth 2015; Ungaretti et al. 2015). A shift to pedagogy underpinned by humanism can provide movement towards the human side of economic agency, rather than traditional economics (Dierksmeier 2016), as humanistic education is concerned with promoting social development (Leach 2018). There is a developing critical stream of entrepreneurship education research that seeks to highlight alternative ways to underpin and teach entrepreneurship in order to move the field away from supporting the neoliberal paradigm (e.g., Berglund \& Verduyn 2018; Lackéus 2017). Applying a humanistic philosophy to underpin entrepreneurship education can support such a move. Such a movement away from the neoliberal paradigm can help to support entrepreneurship education to be opened up to learners 
from a wide range of disciplines, especially outside of the business school, allowing them to follow a path of entrepreneurship not focused solely on profit maximisation.

Philosophical assumptions within humanism include that the learner is autonomous, capable of smart decision-making, possessing an urge towards self-actualisation, and are focused on their own growth and development (Elias and Merriam 1995; Leach 2018). Therefore, the learner can direct their own learning to maximise their own personal growth (Morris 2019b). It is proposed that such self-directed learning can prepare learners to deal with future challenges inherent in rapidly changing environments (Rogers 1969) and can play an important part in entrepreneurial learning. Similar to constructivism, humanism promotes learning through experience and doing, which has widely been proposed as essential for developing entrepreneurs (Jones and Iredale 2010).

Underpinning learning and pedagogy with humanism leads to a redefinition of both how learners should learn, and what they should learn, so that in the future they will have the skills and outlook to act in a positive manner (Schaltegger and Wagner 2011; Hesselbarth and Schaltegger 2014; Greenberg 2015). Laasch and Moosmayer (2015) suggest that humanism provides a transition from the learning of competences to the learning for competence in the ever changing and adapting economic environment. Humanism seeks to move learning from being a socially isolated activity to a more relational activity, and from a perspective of learner's selfinterest to a more community-oriented perspective (Dierksmeier 2020). Humanistic learning environments are characterised by relationships, community, respect, and consciousness, and it has been found that the application of these characteristics in the classroom can foster and support the development of post-industrial social skills (Leach 2018).

Within a humanistic learning environment, educators demonstrate care by connecting with learners outside of the class through promoting social bonds (Brown 2003; Weinstein et al. 2003). Educators act as a coach or mentor in the co-learning process (Hannon 2005) and engage with discussions about learner's feelings and support their emotional well-being (Ullucci 2009). Such actions have been highlighted as important when supporting learners learning 'for' entrepreneurship and 'through' entrepreneurship, as supporting learners in these scenarios involves connecting with learners outside of the classroom to ensure that the learners engage with real audiences to develop their entrepreneurial skills and behaviours. Literature also highlights the need to support learners' emotional well-being to develop resilient learners, as the entrepreneurial learning process commonly involves failure (Shepherd 2004; Testa and Frascheri 2015), and learning from such failure is important in supporting learners to try again (Kauppinen et al. 2019). Failing to control and adequately support learner failures in entrepreneurship education has been posited as a potential 'dark side' of entrepreneurship education (Bandera et al. 2020). To support learners learning from failure, it is important to engage with learners' emotions as this can contribute to learners in achieving the learning outcomes, and educators can facilitate this process (Rose et al. 2019).

Within humanistic learning environments there should be positive and respectful interactions between peers, in a warm, accepting, and nonthreatening atmosphere (Allender 2001). Therefore, it is essential that the educator creates a safe 
environment where learners respect each other's views (Leah 2018). As in constructivist learning environments the educator should support positive constructive criticism and feedback, although this can be challenging for learners who are not familiar with such an approach (Bell 2020b).

A growing focus within entrepreneurship education is value creation pedagogy, which focuses on learners learning through creating value to at least one external stakeholder outside their group, class, or school (Lackéus et al. 2016). This is in line with the definition of entrepreneurship as it involves acting upon opportunities and ideas and transforming them into value for others (Vestergaard et al. 2012), and it enables learners to meet several of the tenets within humanism through designing and directing their own projects, working with communities and building relationships in the pursuit of identifying opportunities and creating value for stakeholders. Such an approach can put less focus on neoliberal economic principles and could more effectively suit contexts where the entrepreneurial learning goals are more social developmental focused, potentially making it more acceptable to educators in non-business disciplines (Lackéus et al. 2016) and education in socialist market economies (Bell 2020a).

Having discussed behaviourism, cognitivism, constructivism, and humanism, and the benefits of these and how they can be applied in the entrepreneurship classroom to underpin pedagogy, the next section will conclude by presenting an overview of some of the practicalities that are involved.

\section{Conclusion}

This paper has linked educational philosophy and theory to entrepreneurship education and practice by discussing and highlighting how behaviourism, cognitivism, constructivism, and humanism can be used to underpin and support learning in entrepreneurship education. This has contributed to the literature by meeting calls to provide connections between educational theory and entrepreneurship education practice (Fayolle et al. 2016) by providing links between education literature, theory, and learning (Neergaard et al. 2020) and conceptualising how educational philosophies and theory can be integrated into entrepreneurship education to support learners (Bell and Bell 2020).

It is important for educators to understand the philosophies that underpin entrepreneurship education pedagogy and practice, to have a deeper understanding of how to deliver it and the reasoning behind it (Hannon 2006). The educational philosophy and theory of learning chosen by the educator informs and guides the teaching practice which will have implications on what they deliver, how it is delivered, and how they undertake assessment of the learners. The main features of the four approaches discussed in this paper are summarised below.

The traditional behaviourist approach is based on the didactic transmission of objectivist knowledge. Repetition, reinforcement, and the testing of learned facts are common features in this approach. It is a convenient vehicle, based on efficient and functional mechanical processes (Löbler 2006). It is efficient for the delivery of factual knowledge and instructional information. However, it can stifle creativity and 
only requires learners to feed back the information. In entrepreneurship education, it can be used to provide the theory of entrepreneurship, the process, and the value. In this way, it can support the teaching of the 'about' entrepreneurship.

Cognitivism builds on behaviourism by supporting the development of objectivist knowledge, but also supports learners to critically analyse problems and situations through the processing of existing knowledge in relation to unique and developing situations to inform decision making. Through this, learners can develop the critical thinking skills that are essential in business and entrepreneurship to support making informed and reasoned assessments to support decision making. Developing critical thinking skills can be part of the teaching 'for' entrepreneurship. However, cognitivism alone is likely to struggle to fully prepare learners for entrepreneurship due to its limited ability to help learners to relate experience to knowledge and context through reflection which is important within entrepreneurship. The ability for entrepreneurs to understand 'how' and be able to learn from their entrepreneurial experiences has been highlighted as crucial to the entrepreneurial process (Ferreira 2020).

Constructivism involves individuals constructing their own meaning on reflection from experience, in relation to their own context and experience. Constructivism builds on cognitivism in that learners need to apply critical thinking skills to solve a problem or task in context, and then produce meaning from the experience through reflection. This can support the development of key entrepreneurial skills 'for' entrepreneurship and 'through' entrepreneurship depending on the context, the individual, and the experience. 'Through' entrepreneurship would involve a real entrepreneurial experience whilst 'for' entrepreneurship would involve a less authentic experience designed to develop more general skills. It is widely argued that approaches based on constructivism are the most efficacious for entrepreneurship education (Balan and Metcalfe 2012; Kyrö 2015).

Humanism is like constructivism in that they both support the development of subjective knowledge; however, humanism provides a different lens to the learning process. Humanism promotes the acquisition of value-oriented skills and the development of integrative judgments within learners. It incorporates personal acts of fulfilment which can include working and engaging with the community. The reduced focus on neo-liberal principles potentially opens entrepreneurship education to a wider audience and greater participation. Like constructivism it can be used both 'for' and 'through' entrepreneurship depending on the task or context.

Importantly, the underpinning educational approach should be in alignment with what the teaching seeks to impart and achieve, and the roles of the educator and learners within the process. It is worth noting that the four approaches are not necessarily exclusive, and different philosophies and theories of learning can be applied to meet different learning objectives in a course or module. For example, the first part of a session can involve a behaviourist approach and the second part a cognitivist or constructivist approach. Indeed, learning approaches based on the development of subjective knowledge require that learners have an adequate grounding in basic objectivist knowledge first, to ensure learners can undertake the task or experience and are able to critically reflect to allow them to make meaning and learn from the experience. However, challenges can exist when moving away from established traditional didactic teaching approaches focused on delivering objective knowledge, 
to approaches which support the delivery of subjective knowledge, as this can be unsettling to learners who need to make a transition to the new teaching structures and rituals (Neergaard and Christensen 2017). Educators can help and support learners to embrace these new approaches until they become comfortable with the process. Similarly, educators may find embracing new approaches difficult and time consuming at first and may prefer to use traditional approaches (Bell and Liu 2019), in which case encouragement and support of the educators may be required. Educators might need to be supported to develop a new mindset when transitioning to different teaching practices (Zhang and Price 2020).

Context is also an important consideration and includes age, education, the critical thinking skills of the cohort and whether the course is intra-or extra-curricular. Learners for example, must have adequate knowledge and critical thinking skills and the ability to be self-directed, before moving to constructivist and humanist experiences which support the creation of subjective knowledge. Institutional contexts might also present challenges to the successful implementation of constructivist and humanistic learning environments, where more traditional behaviourist or cognitivist teaching is the norm (Bell and Liu 2019). In some institutional contexts, the teaching of more subjective knowledge might need to be delivered through extracurricular activities and events (Cui et al. 2019).

Whilst, there is a growing consensus that educational and pedagogic approaches which support the development of subjective knowledge are the most effective within entrepreneurship education, it is essential that learners have the underpinning knowledge and critical thinking skills to support learning within subjective learning processes. This means that often a range of educational philosophies and theories will need to be adopted to underpin teaching and pedagogy which seeks to support different educational objectives and outcomes, to develop learners' entrepreneurial behaviours for future entrepreneurship and employment. This aligns with the suggestion from Rae (2005) that entrepreneurship education and entrepreneurial learning requires a holistic lens. It has also been highlighted that it is essential to find a suitable balance between approaches to achieve the desired learning objectives and impact on the learners (Kirby 2004).

\section{Limitations and future research}

Whilst, this paper outlines how a range of educational approaches can be applied to underpin entrepreneurship education, individual educators will need to determine what the goals and objectives of their educational programs will be, and which educational philosophies and theories are most appropriate for achieving these goals and objectives in their context. Within this paper, the application and pertinence of the philosophies and theories considered have been unpacked in relation to higher education. It may, however, have transferability and be of value to educators in other settings and at other levels. Whilst the educational philosophies and theories might be applicable across a range of contexts and levels, their prominence will likely need to be adjusted to match the different educational goals and cohort characteristics at different levels. It should also be acknowledged that institutional factors and 
expectations might necessitate a particular educational approach and underpinning philosophy and theory of learning, limiting the ability of the educator to determine their own approach. Additionally, whilst this paper posits the benefits of using a mix of educational philosophies and theories to support the learner's development in entrepreneurship education, it does not explore how to effectively transition between educational philosophies and theories in the classroom, which would benefit from greater exploration.

Whilst this paper is purely conceptual, it lays the groundwork for empirical research to explore the application of different learning approaches and educational philosophies and theories. Future research could explore how educators and learners embrace humanistic entrepreneurship education processes. Links could also be drawn to the potential benefits (and limitations) of humanistic approaches to entrepreneurship education and how this supports the development of entrepreneurs and entrepreneurial behaviours. The educational philosophies and theories of learning considered in this paper are not exhaustive and the field would still benefit from greater application of philosophy and theory.

\section{Acknowledgments None}

Author contributions None.

Funding The paper received no funding.

\section{Compliance with ethical standards}

Conflict of interest On behalf of all authors, the corresponding author states that there is no conflict of interest.

Open Access This article is licensed under a Creative Commons Attribution 4.0 International License, which permits use, sharing, adaptation, distribution and reproduction in any medium or format, as long as you give appropriate credit to the original author(s) and the source, provide a link to the Creative Commons licence, and indicate if changes were made. The images or other third party material in this article are included in the article's Creative Commons licence, unless indicated otherwise in a credit line to the material. If material is not included in the article's Creative Commons licence and your intended use is not permitted by statutory regulation or exceeds the permitted use, you will need to obtain permission directly from the copyright holder. To view a copy of this licence, visit http://creativecommons.org/licen ses/by/4.0/.

\section{References}

Allender, J. (2001). Teacher self: The practice of humanistic education. Lanham, MD: Rowman \& Littlefield.

Ally, M. (2004). Foundations of educational theory for online learning. In T. Anderson (Ed.), The theory and practice of online learning (pp. 16-44). Edmonton, AB: AU Press.

Aloni, N. (2002). Enhancing humanity: The philosophical foundations of humanistic education. Boston, MA: Kluwer Academic Press.

Arghode, V., Brieger, E., \& Wang, J. (2018). Engaging instructional design and instructor role in online learning environment. European Journal of Training and Development, 42(7/8), 366-380. 
Balan, P., \& Metcalfe, M. (2012). Identifying teaching methods that engage entrepreneurship students. Education + Training, 54(5), 368-384.

Bandera, C., Santos, S., \& Liguori, E. (2020). The dark side of entrepreneurship education: A delphi study on dangers and unintended consequences. Entrepreneurship Education and Pedagogy. https ://doi.org/10.1177/2515127420944592.

Bandura, A. (1977). Social learning theory. New Jersey: Prentice-Hall.

Béchard, J.-P., \& Toulouse, J.-M. (1998). Validation of a didactic model for the analysis of training objectives in entrepreneurship. Journal of Business Venturing, 13(4), 317-332.

Bélanger, P. (2011). Theories in adult learning and education. Leverkusen: Barbara Budrich Publishers.

Bell, R. (2020a). Developing entrepreneurial behaviours in the Chinese classroom through value creation pedagogy. Innovations in Education and Teaching International. https://doi.org/10.1080/14703 297.2020.1793800.

Bell, R. (2020b). Adapting to constructivist approaches to entrepreneurship education in the Chinese classroom. Studies in Higher Education, 45(8), 1694-1710.

Bell, R. (2016). Unpacking the link between entrepreneurialism and employability: An assessment of the relationship between entrepreneurial attitudes and likelihood of graduate employment in a professional field. Education + Training, 58(1), 2-17.

Bell, R., \& Bell, H. (2016). An enterprise opportunity for entrepreneurial students: Student enterprise development and experience assessed through the student voice. Education + Training, 58(7/8), 751-765.

Bell, R., \& Bell, H. (2020). Applying educational theory to develop a framework to support the delivery of experiential entrepreneurship education. Journal of Small Business and Enterprise Development, 27(6), 987-1004.

Bell, R., \& Liu, P. (2019). Educator challenges in the development and delivery of constructivist active and experiential entrepreneurship classrooms in Chinese vocational higher education. Journal of Small Business and Enterprise Development, 26(2), 209-227.

Bennett, R. (2006). Business lecturers' perceptions of the nature of entrepreneurship. International Journal of Entrepreneurial Behavior \& Research, 12(3), 165-188.

Berglund, K., \& Verduijn, K. (2018). Revitalizing entrepreneurship education: Adopting a critical approach in the classroom. New York: Routledge.

Biggs, J. (2012). What the student does: Teaching for enhanced learning. Higher Education Research \& Development, 31(1), 39-55.

Billings, D., \& Halstead, J. (2019). Teaching in nursing: A guide for faculty. St. Louis, MO: Elsevier.

Bozward, D., \& Rogers-Draycott, M. C. (2020). Value creation programmes: Lessons from an earlystage implementation. Entrepreneurship Education, 3, 287-310.

Brieger, E., Arghode, V., \& McLean, G. (2020). Connecting theory and practice: Reviewing six learning theories to inform online instruction. European Journal of Training and Development, 44(4/5), 321-339.

Brown, D. F. (2003). Urban teachers' use of culturally responsive management strategies. Theory Into Practice, 42(4), 277-282.

Bruner, J. (1966). Towards a theory of instruction. Boston, MA: Harvard University Press.

Chakraborty, M., \& Muyia Nafukho, F. (2014). Strengthening student engagement: What do students want in online courses? European Journal of Training and Development, 38(9), 782-802.

Cope, J. (2005). Toward a dynamic learning perspective of entrepreneurship. Entrepreneurship Theory and Practice, 29(4), 373-397.

Cui, J., Sun, J., \& Bell, R. (2019). The impact of entrepreneurship education on the entrepreneurial mindset of college students in China: The mediating role of inspiration and the role of educational attributes. The International Journal of Management Education. https://doi.org/10.1016/j. ijme.2019.04.001.

Darkenwald, G., \& Merriam, S. (1982). Adult education: Foundations of practice. New York: Harper \& Row.

Dewey, J. (2013). Essays in experimental logic. Mineola, NY: Dover Publications.

Dierksmeier, C. (2011). The freedom-responsibility nexus in management philosophy and business ethics. Journal of Business Ethics, 101(2), 263-283.

Dierksmeier, C. (2016). Reframing economic ethics: The philosophical foundations of humanistic management. Cham: Springer.

Dierksmeier, C. (2020). From Jensen to Jensen: Mechanistic management education or humanistic management learning? Journal of Business Ethics, 166(1), 73-87. 
Eisler, R. T., Loye, D., \& Eisler, R. T. (1990). The partnership way: New tools for living and learning. San Francisco, CA: Harper.

Elias, J. L., \& Merriam, S. (1995). Philosophical foundations of adult education. Melbourne, FL: Krieger Publishing.

Ertmer, P. A., \& Newby, T. J. (2013). Behaviorism, cognitivism, constructivism: Comparing critical features from an instructional design perspective. Performance Improvement Quarterly, 26(2), 43-71.

Facione, P. (1990). The California critical thinking skills test: College level. Millbrae, CA: California Academic Press.

Fayolle, A. (2013). Personal views on the future of entrepreneurship education. Entrepreneurship \& Regional Development, 25(7-8), 692-701.

Fayolle, A., Verzat, C., \& Wapshott, R. (2016). In quest of legitimacy: The theoretical and methodological foundations of entrepreneurship education research. International Small Business Journal, 34(7), 895-904.

Ferreira, C. (2020). Experiential learning theory and hybrid entrepreneurship: Factors influencing the transition to full-time entrepreneurship. International Journal of Entrepreneurial Behavior \& Research, 26(8), 1845-1863.

Freire, P. (2006). Banking versus problem-solving models of education. In R. Curren (Ed.), Philosophy of education: An anthology (pp. 68-75). Malden, MA: Wiley-Blackwell.

Freire, P., \& Faundez, A. (1989). Learning to question: A pedagogy of liberation. Geneva: World Council of Churches.

Fuchs, K., Werner, A., \& Wallau, F. (2008). Entrepreneurship education in Germany and Sweden: What role do different school systems play? Journal of Small Business and Enterprise Development, 15(2), 365-381.

Gedeon, S. (2014). Application of best practices in university entrepreneurship education: Designing a new MBA program. European Journal of Training and Development, 38(3), 231-253.

Gergen, K. J. (2015). An invitation to social construction. Los Angeles, CA: Sage Publications.

Greenberg, D. N. (2015). Globally responsible leadership: Managing according to the U.N. global compact. Academy of Management Learning \& Education, 14(2), 297-299.

Hägg, G., \& Kurczewska, A. (2016). Connecting the dots: A discussion on key concepts in contemporary entrepreneurship education. Education + Training, 58(7/8), 700-714.

Halpern, D. F. (1996). Thought and knowledge: An introduction to critical thinking. Mahwah, NJ: Lawrence Erlbaum.

Hannon, P. (2006). Teaching pigeons to dance: Sense and meaning in entrepreneurship education. Education + Training, 48(5), 296-308.

Hannon, P. (2005). Philosophies of enterprise and entrepreneurship education and challenges for higher education in the UK. The International Journal of Entrepreneurship and Innovation, 6(2), $105-114$.

Hesselbarth, C., \& Schaltegger, S. (2014). Educating change agents for sustainability - learnings from the first sustainability management master of business administration. Journal of Cleaner Production, 62, 24-36.

Hmelo-Silver, C. E. (2004). Problem-based learning: What and how do students learn?'. Educational Psychology Review, 16(3), 235-266.

Hmelo-Silver, C. E., Duncan, R. G., \& Chinn, C. A. (2007). Scaffolding and achievement in problembased and inquiry learning: A response to Kirschner, Sweller, and Clark (2006). Educational Psychologist, 42(2), 99-107.

Honig, B. (2004). Entrepreneurship education: Toward a model of contingency-based business planning. Academy of Management Learning \& Education, 3(3), 258-273.

Huitt, W. (1998). Critical thinking: An overview. Valdosta, GA: Valdosta State University.

Jack, S. L., \& Anderson, A. R. (1999). Entrepreneurship education within the enterprise culture: Producing reflective practitioners. International Journal of Entrepreneurial Behaviour \& Research, 5(3), $110-125$.

Jonassen, H. (1999). Designing constructivist learning environments. In C. Reigeluth (Ed.), Instructionaldesign theories and models: A new paradigm of instructional theory (pp. 215-239). Mahwah, NJ: Lawrence Erlbaum.

Jones, B., \& Iredale, N. (2010). Enterprise education as pedagogy. Education + Training, 52(1), 7-19.

Jones, C. (2019). A signature pedagogy for entrepreneurship education. Journal of Small Business and Enterprise Development, 26(2), 243-254. 
Kantar, L. D. (2013). Demystifying instructional innovation: The case of teaching with case studies. Journal of the Scholarship of Teaching and Learning, 13(2), 101-115.

Kauppinen, A., Paloniemi, K., \& Juho, A. (2019). Failed firm founders' grief coping during mentoring: Learning as the single catalyst of their restarting performance narratives. The International Journal of Management Education. https://doi.org/10.1016/j.ijme.2019.02.008.

Kirby, D. A. (2004). Entrepreneurship education: Can business schools meet the challenge? Education + Training, 46(8/9), 510-519.

Korsgaard, S., \& Anderson, A. R. (2011). Enacting entrepreneurship as social value creation. International Small Business Journal, 29(2), 135-151.

Kyrö, P. (2015). The conceptual contribution of education to research on entrepreneurship education. Entrepreneurship \& Regional Development, 27(9-10), 599-618.

Laasch, O., \& Moosmayer, D. (2015). Competences for responsible management: A structured literature review. CRME Working Paper, 1(2), 1-35.

Lackéus, M. (2017). Does entrepreneurial education trigger more or less neoliberalism in education? Education + Training, 59(6), 635-650.

Lackéus, M., Lundqvist, M., \& Middleton, K. W. (2016). Bridging the traditional-progressive education rift through entrepreneurship. International Journal of Entrepreneurial Behavior \& Research, 22(6), 777-803.

Leach, N. (2018). Impactful learning environments: A humanistic approach to fostering adolescents' postindustrial social skills. Journal of Humanistic Psychology. https://doi.org/10.1177/0022167818 779948.

Lester, S. W., Tomkovick, C., Wells, T., Flunker, L., \& Kickul, J. (2005). Does service-learning add value? Examining the perspectives of multiple stakeholders. Academy of Management Learning \& Education, 4(3), 278-294.

Löbler, H. (2006). Learning entrepreneurship from a constructivist perspective. Technology Analysis \& Strategic Management, 18(1), 19-38.

Lorsbach, A., \& Tobin, K. (1992). Constructivism as a referent for science teaching. In F. Lorenz, K. Cochran, J. Krajcik, \& P. Simpsons (Eds.), Research matters to the science teachers (pp. 3-21). New York: NARST.

Macht, S. A., \& Ball, S. (2016). 'Authentic Alignment' - A new framework of entrepreneurship education. Education + Training, 58(9), 926-944.

Mathews, M. (2007). Constructivist pedagogy for the business communication classroom. Journal of College Teaching \& Learning, 4(11), 99-106.

Merriam, S. (1982). Some thoughts on the relationship between theory and practice. In S. Merriam (Ed.), Linking philosophy and practice: New directions for continuing education (pp. 87-91). San Francisco, CA: Jossey-Bass.

Merriam, S., Caffarella, R., \& Baumgartner, L. (2007). Learning in adulthood: A comprehensive guide. San Francisco, CA: Jossey-Bass.

Meyers, C. (1986). Teaching students to think critically. San Francisco, CA: Jossey-Bass.

Mezirow, J. (1990). Fostering critical reflection in adulthood. San Francisco, CA: Jossey-Bass.

Mirowski, P. (1989). More heat than light: Economics as social physics, physics as nature's economics. Cambridge: Cambridge University Press.

Morrell, K., \& Learmonth, M. (2015). Against evidence-based management, for management learning. Academy of Management Learning \& Education, 4(4), 520-533.

Morris, T. H. (2019a). Adaptivity through self-directed learning to meet the challenges of our ever-changing world. Adult Learning, 30(2), 56-66.

Morris, T. H. (2019b). Self-directed learning: A fundamental competence in a rapidly changing world. International Review of Education, 65(4), 633-653.

Morris, T. H. (2020). Creativity through self-directed learning: Three distinct dimensions of teacher support. International Journal of Lifelong Education, 39(2), 168-178.

Mueller, S., \& Anderson, A. R. (2014). Understanding the entrepreneurial learning process and its impact on students' personal development: A European perspective. The International Journal of Management Education, 12(3), 500-511.

Nabi, G., \& Holden, R. (2008). Graduate entrepreneurship: Intentions, education and training. Education + Training, 50(7), 545-551.

Neck, H., \& Greene, P. (2011). Entrepreneurship education: Known worlds and new frontiers. Journal of Small Business Management, 49(1), 55-70. 
Neck, H., \& Corbett, A. (2018). The scholarship of teaching and learning entrepreneurship. Entrepreneurship Education and Pedagogy, 1(1), 8-41.

Neergaard, H., \& Christensen, D. (2017). Breaking the waves: Routines and rituals in entrepreneurship education. Industry and Higher Education, 31(2), 90-100.

Neergaard, H., Gartner, W. B., Hytti, U., Politis, D., \& Rae, D. (2020). Editorial. International Journal of Entrepreneurial Behavior \& Research, 26(5), 817-828.

O'Brien, E., Cooney, T. M., \& Blenker, P. (2019). Expanding university entrepreneurial ecosystems to under-represented communities. Journal of Entrepreneurship and Public Policy, 8(3), 384-407.

Örtenblad, A., Koris, R., Farquharson, M., \& Hsu, S. (2013). Business school output: A conceptualisation of business school graduates. The International Journal of Management Education, 11(2), 85-92.

Peltier, J. W., \& Scovotti, C. (2010). Enhancing entrepreneurial marketing education: The student perspective. Journal of Small Business and Enterprise Development, 17(4), 514-536.

Pittaway, L., \& Cope, J. (2007). Entrepreneurship education: A systematic review of the evidence. International Small Business Journal, 25(5), 479-510.

Platzer, H., Snelling, J., \& Blake, D. (1997). Promoting reflective practitioners in nursing: A review of theoretical models and research into the use of diaries and journals to facilitate reflection. Teaching in Higher Education, 2(2), 103-121.

Rae, D. (2005). Entrepreneurial learning: A narrative-based conceptual model. Journal of Small Business and Enterprise Development, 12(3), 323-335.

Ramsgaard, M. B. (2018). Experiential learning philosophies of enterprise and entrepreneurship education. In D. Hyams-Ssekasi \& E. F. Caldwell (Eds.), Experiential learning for entrepreneurship (pp. 3-18). London: Palgrave MacMillan.

Robinson, S., Neergaard, H., Tanggaard, L., \& Krueger, N. F. (2016). New horizons in entrepreneurship education: From teacher-led to student-centered learning. Education + Training, 58(7/8), 661-683.

Rogers, C. (1969). Freedom to Learn. Columbus, OH: Charles Merill.

Rose, A.-L., Leisyte, L., Haertel, T., \& Terkowsky, C. (2019). Emotions and the liminal space in entrepreneurship education. European Journal of Engineering Education, 44(4), 602-615.

Schaltegger, S., \& Wagner, M. (2011). Sustainable entrepreneurship and sustainability innovation: Categories and interactions. Business Strategy and the Environment, 20(4), 222-237.

Sewell, P., \& Dacre Pool, L. (2010). Moving from conceptual ambiguity to operational clarity: Employability, enterprise and entrepreneurship in higher education. Education + Training, 52(1), 89-94.

Shepherd, D. A. (2004). Educating entrepreneurship students about emotion and learning from failure. Academy of Management Learning \& Education, 3(3), 274-287.

Snowman, J., \& Biehler, R. F. (2006). Psychology applied to teaching. Boston, MA: Houghton Mifflin.

Solberg, J., Strong, K. C., \& McGuire, C. (1995). Living (not learning) ethics. Journal of Business Ethics, 14(1), 71-81.

Testa, S., \& Frascheri, S. (2015). Learning by failing: What we can learn from un-successful entrepreneurship education. The International Journal of Management Education, 13(1), 11-22.

Trigwell, K., Prosser, M., \& Waterhouse, F. (1999). Relations between teachers' approaches to teaching and students' approaches to learning. Higher Education, 37(1), 57-70.

Ullucci, K. (2009). 'This has to be family': Humanizing classroom management in urban schools. The Journal of Classroom Interaction, 44(1), 13-28.

Ungaretti, T., Thompson, K. R., Miller, A., \& Peterson, T. O. (2015). Problem-based learning: Lessons From medical education and challenges for management education. Academy of Management Learning \& Education, 14(2), 173-186.

Vestergaard, L., Moberg, K., \& Jørgensen, C. (2012). Impact of entrepreneurship education in Denmark. Odense: Young Enterprise Denmark.

Weinstein, C., Curran, M., \& Tomlinson-Clarke, S. (2003). Culturally responsive classroom management: Awareness into action. Theory Into Practice, 42(4), 269-276.

Zhang, J. (2020). Pedagogical alignment for entrepreneurial development. Entrepreneurship Education, 3(3), 239-244.

Zhang, J., \& Price, A. (2020). Developing the enterprise educators' mindset to change the teaching methodology: The case of Creating Entrepreneurial Outcomes (CEO) Programme. Entrepreneurship Education, 3(3), 339-361.

Publisher's Note Springer Nature remains neutral with regard to jurisdictional claims in published maps and institutional affiliations. 